\title{
Liability of Negotiation in the Procurement of Art Entertainment Services of Javanese Karawitan Tradition in Surakarta
}

\author{
Eko Joko Trihadmono \\ Doctoral Student of Postgraduate Program \\ Universitas Sebelas Maret \\ Surakarta, Indonesia \\ ekojokoplengeh@gmail.com
}

\section{Sumarlam}

Postgraduate Program,

Universitas Sebelas Maret

Surakarta Indonesia

sumarlam@staff.uns.ac.id

\author{
Djatmika \\ Postgraduate Program, \\ Universitas Sebelas Maret \\ Surakarta Indonesia \\ djatmika@staff.uns.ac.id \\ Joko Nurkamto \\ Postgraduate Program, \\ Universitas Sebelas Maret \\ Surakarta Indonesia \\ jokonurkamto@gmail.com
}

\begin{abstract}
The objective of this research is to describe various strategies of linguistic politeness used by entertainment service users (penanggap) and performers in negotiation for Javanese karawitan art entertainment service procurement in Surakarta region. The politeness strategies employed by the penanggap and performers in negotiation for the entertainment service procurement refer to the notion of Cooperative Principles initiated by Grice with an aim that the conversations or communications run smoothly, effectively, and efficiently. Grice describes the cooperative principles into four maxims, namely: the maxim of quantity, the maxim of quality, the maxim of relation, and the maxim of manner.Thus, the penanggap and communities who are willing to use the entertainment service, must be smart in negotiating. In other words, the penanggap can bring in passable entertainments with affordable prices through great bargain. In addition, the performers, art group managements, and their members are recommended to have negotiations for the entertainments they offer, but not to leave the politeness principles in negotiating.
\end{abstract}

Keywords: Politeness, negotiation, entertainment service users ('penanggap'), performers, entertainment service.

\section{INTRODUCTION}

A person's language politeness is reflected in the procedures of communication through verbal signs or language procedures. If a person's speech is not in accordance with cultural norms, he will get a negative value, for example to be accused of being arrogant, pompous, indifferent, selfish, uncivilized, or even not cultured.

As a member of society, everyone, whether he likes or dislikes, puts the imposition on others, ultimately creating dependence on each other. Thus, one cannot possibly act only at his own will. That is, every individual willoften, intentionally or by accident, be faced with situations that will force him to judge himself, others, and his communication he deals with and he will clearly show the boundaries of his position.
Usually when njawani people (people who live in Javanese style) especially in Surakarta region, hold celebrations such as weddings, circumcisions, and other parties, they are enlivened with entertainment / pasugatan. Various kinds of entertainment are art of karawitan, keroncong, dance, campursari, electone music, and shadow puppets. From these various interests came an idea of how to present a festive gamelan music (karawitan) group in exchange for affordable services.

One's skill in negotiation or bargaining when entering into an agreement with an artist will benefit the former. The service user's skill in the negotiation will give him lively entertainment but at an affordable price. It will give him satisfaction.

In negotiations, a strategy with various reasons are often usedbut the main objective is cost reduction. However, there are ashamed service users who do not want to use the strategy and negotiate the nominal agreement of the entertainment services. They usually take their siblings or hand them over to an intermediary in negotiation.

Negotiation is a bargaining process by negotiating for giving or receiving in order to reach a mutual agreement between the service user and the artist. It will go tough if both parties mutually maintain the ego and entertainment service standards and it will result in the impression negotiate rigidly. Usually the service user bring a member of his family or relatives to make the negotiating process smooth.

In order to focus and make a comprehensive analysis, researches limit research on the location of the study that takes place in the Surakarta region since Surakarta is famous for its Javanese culture. 


\section{THEORETICAL FRAMEWORK}

\section{Theory of Liability}

Liability, according to Fraser (1990), consists of four functions, namely social-norm view, conversational maxim, conversational contract, and social indexing. Liability in social norms is politeness in speaking which is determined by social and cultural norms that exist and are applied in that society. Liability in speech, according to this view, can be paralleled with language etiquette which also means polite language.

Leech explains liabilityas more reliant on the four notions, namely (1) cost and benefit, (2) agreement, (3) approbation, and sympathy / antipathy. These four motions were used by Leech (1983 and 2005) to formulate the Principles of Courtesy which are translated into the following six maxims.

(1) Tact maxim.

(a) Minimizing costs for others.

(b) Maximizing profits for others.

(2) Generosity maxim

(a) Minimizing benefits for yourself.

(b) Maximizing the cost for yourself

(3) Approbation maxim

(a) Minimizing critiques to others

(b) Maximizing praise to others

(4) Modesty maxim

(a) Minimizingpraise toyourself

(b) Maximizingcritiquesto yourself

(5) Agreement maxim

(a) Minimizingdisagreementwith others

(b) Maximizingagreementwith others

(6) Sympathy maxim

(a) Minimizingantipathyto others

(b) Maximizing sympathyto others

The liability notions, according to Gunarwan (2000 and 2005), are also called the principles of harmony which refer to the necessity of each individual to maintain a social balance / harmony. The essence of the principles of harmony is an attempt to avoid conflict which is associated to four thimbles, namely the thimble of kurmat (respect); thimble of andhapasor (humble); thimble of empan papan (aware of the place); and thimble of tepaslira (tolerance).

Speakers are said to meet the kurmat thimble, if they use a language that makes them respectful for their position. The subbidal on the kurmat thimble is (1) the speakers are prohibited from using language that makes them feel out of proper place and (2) the speakers are encouraged to choose the level of speech and to use honorifics corresponding to the position of the speakers and the social distance between them and their listenerswhen it is necessary.

\section{Theory of Negotiation}

Negotiation is a process whereby two parties reach an agreement that satisfies both parties concerning with elements of cooperation and competition (Kozicki, 2005) including actions taken when communicating, cooperating or influencing others for a particular purpose. An example negotiation is when Christopher Columbus convinced Queen Elizabeth to finance her expedition when England was in a big war that cost a lot of money.

The purpose of negotiation is to reach agreement, common perception, mutual understanding and approval. In other words it is to achieve a win-win solution. While the benefits of negotiation is to establish cooperation between business entities or individuals with a foundation of mutual understanding that will improve the progress of a company.

\section{MeTHODOLOGY}

This research refers to the design of Spradley (1980: 103 and 1997: 55) which proposed 12 (twelve) research steps invested by The Developmental Research Sequence. However, the researcher modified Spradley's proposal with the following reasons: (1) to efficiently time and labor by combining similar activities, (2) to improve the design of the design, (3) to conduct pilot studies immediately; and (4) to reduce the inconvenience of informants .

Another reason the researcher chose the Spradley model is (1) the Spradley model incorporates the initial research steps (assigning informants and social situations) to the final stage (writing ethnography) so that the linkage between one stage and the other will be apparent in the design. ) Sprintley's design is more flexible, easily tailored to the problems and objectives of the research, and (3) within Spradley's designs research data is maintained within the context and is expected to facilitate data analysis in terms of data attribution to the context.

\section{FINDING AND DISCUSSION}

To prove that the bargain in the procurement of entertainment services is interesting to examine, here are two examples of the data below.

Data (I)

Context:

Venue: In the house of the Artist, Sragen; Name: Sumadi; Age: 55; Educational Background: High School; Karawitan group: Mudho Laras

Customer(1) :Kula kepengin banget, niku nek dugi mrika niku, pinten to Pak? (I would love to use your kerawitan services in my place. How much does it cost, sir?)

Sumadi (2) : :Ha, niku pitung yuta mawon! (Er..., just seven million.)

Penanggap (3) :Wah, kok dhuwur nggih? Pitung yutaniku lhe? (That is very expensive, seven million)

Sumadi(4) :Dhaerah Jogja, Gunung Kidul? Teng Gunung Kidul niku, nggi kendharaane men, pun pinten mawon? (The cost of transportation from here to Gunungkidul alone is already high.) 
Penanggap(5) :Walah? Mbok ampun semonten to Pak! Wong kula niku... jane asline kula niku mboten, pripun?

Nggih,.. nuwun sewu nggih? Kula niku, termasuke wong ra duwe ngoten lhe. Ning kula pengin tenan niku Pak! (No, not that much. I really do not ..., how should I say it? I'm sorry, I'm a poor man. But I really want it, sir).

Sumadi(6) :Ooo,..niku pun kulajamin pun! (It's okay. But I guarantee it)

Penanggap(7) :Ning anu, nggih kula purun semonten,... ning ngangge biasane penyanyi kok.. penyanyine kalih ngoten pripun? (I would, but prefer to have two singers? What do you say?)

Sumadi(8) :Nggih nek, nek sampeyan ngoten, nggih! $Y a$, idhep-idhep karo golek pasaran. Mengkenek, ning nek ditekoki tanggatangga njenengan nggih ampun omong semonten, mangumbulke! (If you want so, I'd say, "Yes". This is more like an advertising campaign.If you are asked by the neighbors, do not say the price is five million five hundred thousand. Tell them more than that. Okay?)

Data (II)

Context:

Venue: In the house of the Artist, Karanganyar; Name: Ngadino, S.Pd .; Age: 51; Educational Background: Bachelor's Degree; Karawitan Group: Hidayah Laras

Penanggap(1): Karepe tiyang estri kalih anak kula niku, ajeng nyuwun Krawitan king Mojogedang niku. Lha trus sakniki niku,..regine pinten Mas? (My wife and daughter asked me to use the services of this karawitan from Mojogedang. Now what's the price, Bro?)

Ngadino(2): Wah nek krawitan, nek njenengan takon rega, takon rega memang dhuwur! Reganiku..., ning nek mboten takon nggih naming sakentene ngoten, saget. Ning nek jenengan takon rega niku rega niku... lha pripun nanggape komplit napa naming yaga thok?. (If you ask about the price to use the services of karawitan, the answer is the price is high! But if you do not ask about the price and just want a simple, the price will be cheaper. How do you want it, then? Do you want a complete one or just the crew?)

Penanggap(3): Nggih ngapunten nggih Mas nggih? Gandheng niku, kula niku estu nek tiyang boten gadhah. Gandheng anak kula niku remene ngoten, ajeng nyuwun klenengan. Niku upami.. enem ngoten pripun Mas?
(Sorry, Bro? I am a poor man but my son likes karawitan, what about six million, Bro?)

Ngadino(4):Wa,.. lha niki sakniki niku, napa-napa mundhak Mas. Ndhek mben, dhek lagi bensin dereng mundhak ngeten niki mesthine nggih saget. Nek sak niki nggih dereng saget. Soale njenengan takon rega, nganyang kok? Mesthine nek enem dereng saget niku? (Now the price of all the goods goes up, Bro. When the price of gasoline had not gone up, such prices can do but now it can't. The thing is you ask about prices and negotiate. Six million cannot do)

Penanggap(5): Pun, sakniki amrih dadose Mas! Gandheng kula niku ditangisi anak kula, amrih dadose, pun mang paske ngoten mawon, sedaya amrih kelampahanipun. (Okay, now to make a deal, because I want to realize the wishes of my child, please made the fitting price only)

Ngadino(6): Lha napa kudu krawitan mriki? (Do you have to use the karawitan group of mine?)

The above explanation shows some very interesting linguistic phenomena to be studied further. Lines in data I and data II indicate that the choice of language used by the service user (speaker) with the artist (listener) is the local language, the Javanese. It is influenced by several factors, such as age, educational background, occupation, and their origin in which their daily language is used.

The negotiating conversations took place in the Surakarta region covering: Surakarta, Boyolali, Sukoharjo, Wonogiri, Sragen, and Klaten, shortened as Subosukowonosraten. Javanese language is used very much in this region and the above conversations are only some proofs..The conversations can be analyzed as follows.

The service user starts to negotiate.

\section{Data I}

Line (2)

Ha, niku pitung yuta mawon! (Er..., just seven million.)

Here, the speaker partner implements the maxim of quantity that is 'providing the necessary information'.

Line (5)

Wong kula niku... jane asline kula niku mboten, pripun nggih? Nuwun sewu nggih? Kula niku, termasuke wong raduwe ngoten lhe. Ning kula pengin tenan niku Pak! (No, not that much. I really do not ..., how should I say it? I'm sorry, I'm a poor man. But I really want it, sir)

The line includes acting assertiveness which is claiming about the state of the economy. However, it violates the Cooperation Principle of Maxim of Quality that is 'not saying something that is not true' 


\section{Data II}

Line (1)

Karepe tiyang estri kalih anak kula niku, ajeng nyuwun krawitan king Mojogedang niku. Lha trus sakniki niku, reginepinten Mas? (My wife and daughter asked me to use the services of this karawitan from Mojogedang. Now what's the price, Bro?)

The above line shows a violation of Grice's Cooperation Principle of maxim of mannerthat is 'keeping away from unclear information'. The speaker pretends to be the representative of his wife and daughter to ask the price of entertainment service. He wants to state something, according to assertive acting speech that is stating. He wants to realize the wishes of his wife and daughterto have an entertainment in his daughter's wedding party.

The speaker partnerhas implemented the Liability Principle of tact maxim that is 'minimizing costs for others'. The speaker partnertries to provide solutions forthe speaker, for example inline (2);

Wah nek krawitan, nek njenengan takon rega, takon rega memang dhuwur! Rega niku, ning nek mboten takon nggih naming sakentene ngoten, saget. Ning nek jenengan takon rega niku rega niku, lha pripun nanggape komplit napa naming yaga thok? ((If you ask about the price to use the services of karawitan, the answer is the price is high! But if you do not ask about the price and just want a simple, the price will be cheaper. How do you want it, then? Do you want a complete one or just the crew?)

In making the bargain the speaker uses the modesty maxim that is ' minimizing praise to yourself', for example inline (3) Nggih ngapunten nggih Mas nggih? Gandheng niku, kula niku estu nek tiyang boten gadhah. Gandheng anak kula niku remene ngoten, ajeng nyuwun klenengan. Niku upami.. enem ngoten pripun Mas? ((Sorry, Bro? I am a poor man but my son likes karawitan, what about six million, Bro?)

It also violates the cooperation principle of quality maxim that is 'not saying something that is not true'.

Line (4)

Wa,.. lha niki sakniki niku, napa-napa mundhak Mas. Ndhek mben, dhek lagi bensin dereng mundhak ngeten niki mesthine nggih saget. Nek sakniki nggih dereng saget. Soale njenengan takon rega, nganyang kok? Mesthine nek enem dereng saget niku?(Now the price of all the goods goes up, Bro. When the price of gasoline had not gone up, such prices can do but now it can't. The thing is you ask about prices and negotiate. Six million cannot do.)

Speaker partner does not violate the maxim of quantity that is providing information as many as it is needed. He tries to give the real price and to reject the speaker's offer.

Lines in data I and data II are not by accident and have a difference, ie on data I the speaker uses friendly words. In Data II, the speaker indicates that he is incapable of making the bargaining process work. The speaker partner speaks spontaneously of the speaker's intent. This is in accordance with the opinion of Yule (1996) that pragmatics is a discipline that studies the intentions of speakers. Pragmatics also examines the speaker's motivation in uttering a speech (Gunarwan, 2007).

\section{CONCLUSION}

The findings from the above research indicate that in the negotiation between entertainment service users and the artist, liability is very important. This is an input to the service users and people who want to use entertainment services to choose a polite speech in the negotiations. In other words, service users can bring a pretty good entertainment at a mild cost through a polite and powerful bargaining strategy. In addition, this is also an input for artists, administrators, and art group members that they should obey the rules of politeness in the negotiations.

\section{References}

Austin, J.L (1962). How to do things with words. Cambridge Mass : Harvard University Press.

Fraser, B. (year?) "Perspectives on Politennes"dalam Shoshana Blum-Kulkadan Gabriele Kasper. Jurnal of Pragmatise 14. Nort Holland---Amsterdam. Vol. ? page. $219-236$

Gunarwan, A. (2000). "Tindak Tutur Melarang di Kalangan Dua Kelompok Etnis Indonesia: Ke arah kajian etnopragmatik" dalam PELLBA 13.Jakarta:UnikaAtma Jaya.

Gunarwan, A. (2005). “ Beberapa Prinsip dalam Komunikasi Verbal: Tinjauan Sosiolinguistik dan Pragmatik" dalam Bahasa, Sastra, dan Pengajarannya. Yogyakarta: Penerbit Universitas Sanata Dharma.

Leech, Geoffrey. 1983. The Principles of Pragmatics. New York: Longman Group Limited.

Kozicki, Stephen. 2005. The Creative Negotiator. New Delhi: Mc.Graw Hill.

Spradley, John R. 1997. Metode Etnografi (penerjemah Misbah Zulfa Elizabeth).Yogyakarta : Tiara Wacana. Yule, George. 1996. Pragmatics. Oxford: Oxford University Press. 